\title{
TAX DEBT AND WAYS OF REDUCING IT
}

M.E. Orlova

Kazan Federal University, Institute of Management, Economics and Finance,

Kazan, Russia

V.I. Nasyrova

Kazan Federal University, Institute of Management, Economics and Finance,

Kazan, Russia

S.V. Salmina

Kazan Federal University, Institute of Management, Economics and Finance,

Kazan, Russia

E-mail:ff104@mail.ru

Recepción: 05/08/2019 Aceptación: 20/09/2019 Publicación: 23/10/2019

\section{Gitación sugerida:}

Orlova, M.E., Nasyrova, V.I. y Salmina, S.V. (2019). Tax debt and ways of reducing it. 3C TIC. Cuadernos de desarrollo aplicados a las TIC. Edición Especial, Octubre 2019, 330-345. doi: https://doi.org/10.17993/3ctic.2019.83-2.330-345

Suggested citation:

Orlova, M.E., Nasyrova, V.I. \& Salmina, S.V. (2019). Tax debt and ways of reducing it. 3C TIC. Cuadernos de desarrollo aplicados a las TIC. Special Issue, October 2019, 330-345. doi: https://doi.org/10.17993/3ctic.2019.83-2.330-345 


\section{ABSTRACT}

The article discusses scientific and legal approaches to the classification of tax debt, analyzes the state of tax debt in Russia for the period from 2013 to 2018. The main causes of tax debt are the deterioration of the financial condition of an economic entity, an individual, as a result of the financial crisis in the country, or deliberate evasion of the payment of mandatory payments by the taxpayer himself. Among the factors affecting the increase in tax debt, should be highlighted, the use of such schemes to avoid tax debt as reorganization, liquidation, merger, merger, division, separation. In the context of various classification groups, proposes new classification groups of tax arrears, incl. to expand its analysis and administration. The article clarifies the concepts of tax debt, settled and unregulated tax debt for the purposes of tax administration and conducting analytical work. The directions for the development of tax debt tax administration are proposed. For tax administration purposes would be to use the tax debt classification by type of organizations-debtors, including by type of economic activity. This will improve the performance of the tax authorities to collect tax debts. It seems appropriate to develop a program of actions for administering different types of taxpayers and collecting tax arrears, and in the future, it is possible to prevent the occurrence of tax arrears.

\section{KEYWORDS}

Arrears, Tax debt, Bankruptcy, Unresolved debts, Tax audit, Tax control measures. 


\section{INTRODUCTION}

The tax code of the Russian Federation does not give a legal interpretation of the term "tax debt", but offers only the concept of arrears, as the amount of tax or fee not paid in the period established by the legislation on taxes and fees (Article 11 of the RF Tax Code), which entails the accrual of penalties. This affected the availability of a variety of interpretations of this category by scientists and practitioners. Tax debt is the most important subject of tax administration, since it is a significant destabilizing economic component that affects the formation of state financial resources. Tax debt is the most important subject of tax administration, since it is a significant destabilizing economic component that affects the formation of state financial resources.

\section{METHODOLOGY}

In conducting the study, the methods of comparison and generalization, methods of statistical analysis and methods of analogy for determining risks were used.

\section{RESULTS AND DISCUSSION}

To indicate unfulfilled obligations, "debt" is used in many ways. The Tax Code of the Russian Federation contains only a definition of arrears as the amount of tax or fee that was not paid within the time period established by the legislation on taxes and fees (Article 11 of the Tax Code of the Russian Federation). The term "debt" is used in the Tax Code of the Russian Federation both in respect of taxes and fees, and in respect of fines and penalties without any explanation.

In explanatory dictionaries Ozhegova (1986) and Ushakov (1935), in the Modern Economic Dictionary (Raizberg et al., 1999), debt is the sum of outstanding obligations to be repaid by a business entity within a certain period of time. It is worth noting that the concept of "debt" is used by the legislative authorities, the executive authorities, lawyers, economists, scientists and others. The concept of "tax debt" is presented in the works of many scientists (Picture 1). 
From the above definitions, the authors draw attention to the fact that the tax debt consists of unpaid taxes, fines and penalties. So, such authors as Aushev (2004), Bondar (2011) tax liabilities are unfulfilled tax liabilities, including fines and penalties. Isaev (2000), Lebedev (1998) Also, tax arrears include unpaid taxes and fees, fines and penalties that the tax authorities accrued. The most complete definition is given by Pronin (2016), which is clearly seen in Picture 1.

In our opinion, at present, tax arrears include unfulfilled obligations on taxes, fees, insurance premiums, penalties accrued on them and fines for violating the legislation on taxes and fees. We propose to consolidate the concept of "tax debt" in the Tax Code of the Russian Federation, which is understood as the aggregate of unfulfilled taxpayers, tax agents, payers of fees and insurance premiums in the period established by tax legislation for the payment of taxes, fees, insurance premiums, as well as accrued fees and penalties sanctions on them.

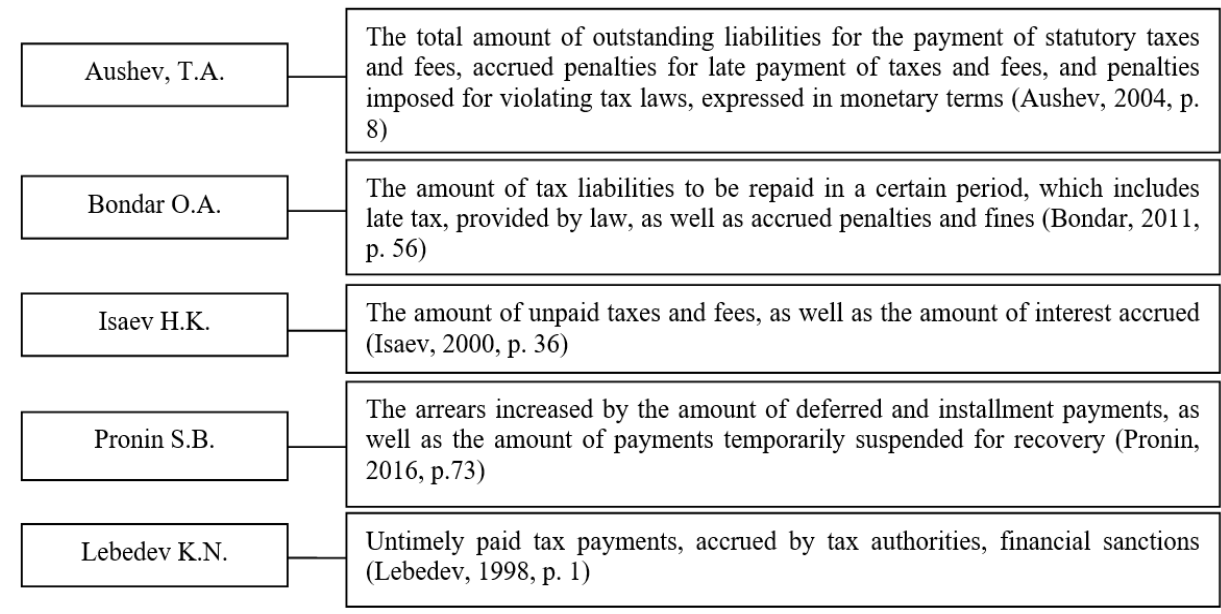

Picture 1. The definition of the concept of "tax debt" proposed by different authors.

Based on the norms of the Tax Code of the Russian Federation, we can identify two main groups of tax debts: current tax debts and tax debts identified in the framework of tax audits (Picture 2). 
In turn, within each group there are three types of tax arrears: arrears (current, arising from the results of tax declaration and accrued according to the calculations of the tax authority; arrears identified as a result of tax audits); arrears of interest accrued as a result of the current arrears; arrears of penalties for current arrears and the results of tax audits; tax arrears accrued as a result of tax audits; tax arrears due as a result of other tax control measures. It should be noted that the current and identified arrears in the process of tax audits have various financial implications. So if there is a current debt, the financial consequence is a penalty, or according to the interpretation of the Tax Code of the Russian Federation, the method of security for tax payment (Article 75 of the Tax Code). If there are arrears identified by the tax authorities based on the results of tax audits, in addition to the penalty, the tax consequence may be a financial consequence. This fact is part of the tax offense.

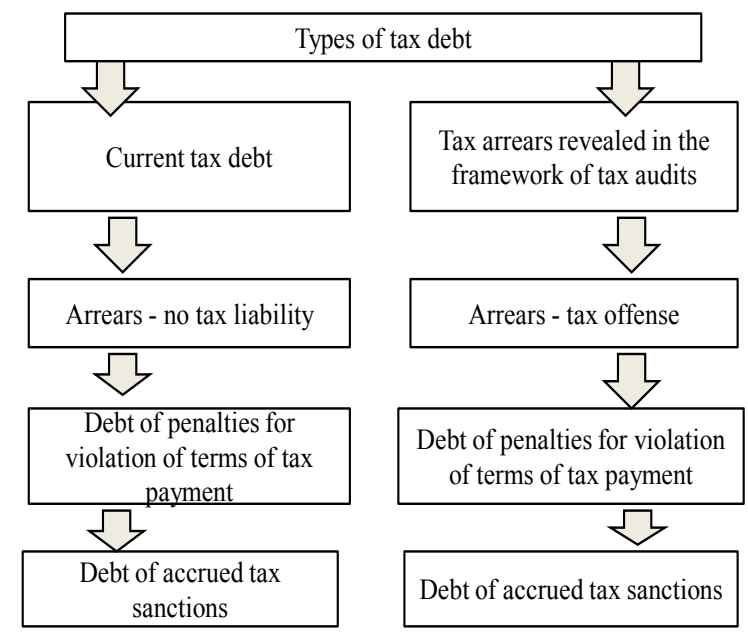

Picture 2. Types of tax debt (Official site of the Federal Tax Service of Russia).

Picture 3 shows the dynamics of tax debt in the context of arrears, penalties and tax sanctions. At the end of 2017, the arrears of interest were $22 \%$, and the tax sanctions $-2.6 \%$. There has been an increase in arrears and a reduction in tax arrears and penalties. 


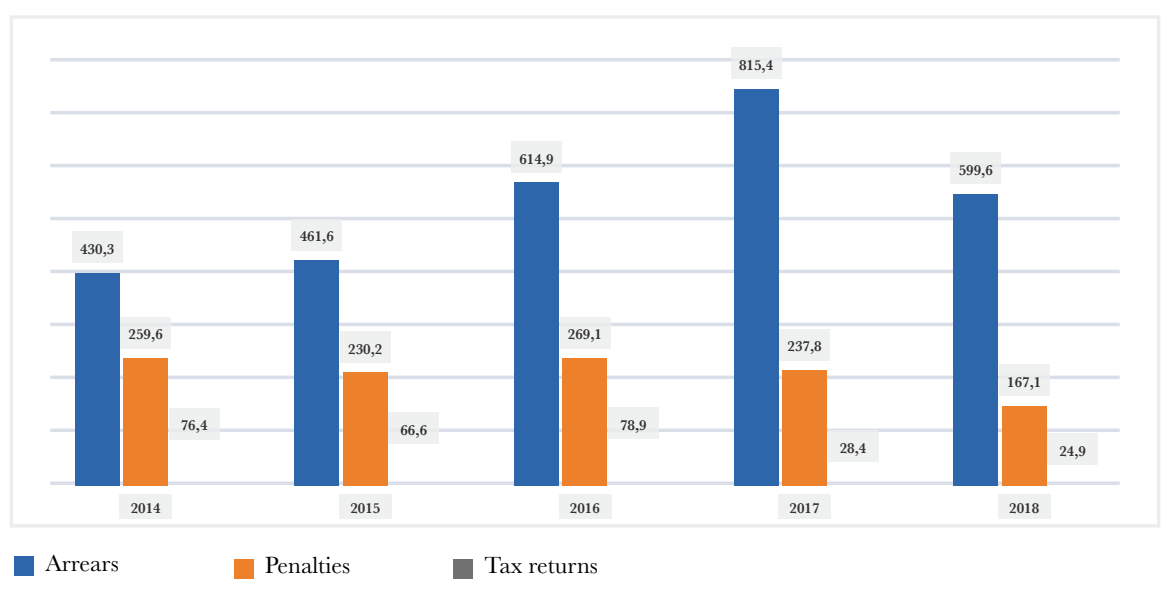

Compiled based on the statements of the Federal Tax Service of Russia (Official site of the Federal Tax Service of Russia).

Picture 3. Dynamics and composition of tax debt as of 01.01.2019.

The main causes of tax debt are the deterioration of the financial condition of an economic entity, an individual, as a result of the financial crisis in the country, or deliberate evasion of the payment of mandatory payments by the taxpayer himself. Among the factors affecting the increase in tax debt, should be highlighted, the use of such schemes to avoid tax debt as reorganization, liquidation, merger, merger, division, separation. A legal entity created by merging with another organization, or reorganized, will not pay anything to the budget, since it will subsequently be liquidated or there will be another way to get rid of it, for example, through another reorganization.

Another reason for the growth of tax debt is the imperfection of the institution of bankruptcy. Most of the enterprises and organizations undergoing bankruptcy proceedings have a significant tax payment debt. At the same time, the implementation of the norms of insolvency (bankruptcy) legislation is the last opportunity for the tax authorities to recover the arrears in payments to the budget and extra-budgetary funds. However, in practice, the bankruptcy process is the least effective measure to recover (repay) tax debt. 
Significant problems exist in the joint work of the tax authorities and the Federal Bailiff Service to execute decisions to collect tax arrears at the expense of the debtor's property, and more specifically, the inability to repay the debt at the expense of liquid assets during the implementation of the enforcement proceedings.

These tax debt problems are not new to tax administration, but effective methods to combat this problem are not enough for today. As practice shows, even if the tax authorities manage to bring the case to court and prove the fact of intentional liquidation, it is practically impossible to collect the debt from the debtor.

Tax debt should be considered as a total tax debt, which consists of settled debt and unresolved debt. Debt settlement includes deferrals and installment plans for the payment of tax payments by the decision of tax authorities, courts, as well as the suspension of penalties until a decision is made by an arbitration court. Unsettled debts include arrears, impossible to collect debts. Tax arrears, fees and insurance premiums affect the revenues of the consolidated budget of the Russian Federation and can lead to a significant reduction in budget expenditures on the most significant projects and programs.

The tax authorities in the framework of statistical reporting distinguish two main types of tax debt: unresolved and settled (see Picture 4).

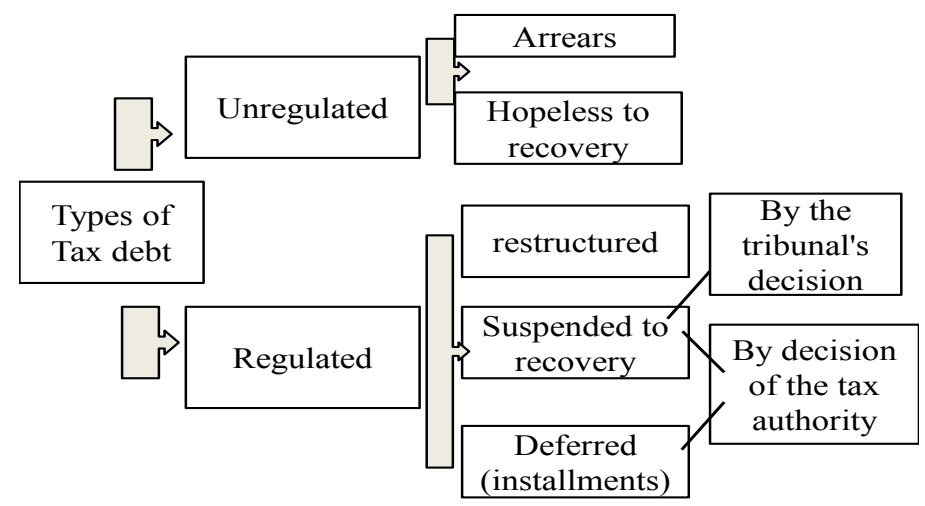

Picture 4. The treatment of types of tax arrears from the point of view of the Federal Tax Service. 
Unsettled debts include arrears and debts uncollectible. The arrears include the amounts of taxes that have not been paid within the prescribed period, in respect of which the terms of application of measures of collection and settlement are valid. The peculiarity of bad debts lies in the fact that they are not subject to collection, restructuring or rescheduling. Bad debts are not subject to regulation due to certain circumstances, such as the death of the taxpayer, the impossibility of establishing its actual location, registration of the taxpayer on forged documents, liquidation in bankruptcy, etc.

Regulated debt, as a rule, is a debt, according to which a certain decision is made on postponement of payments, in particular on restructuring, deferral, installments, investment tax credit, as well as payments suspended for collection in connection with the relevant decision of the tax authority or entered into force of a judicial act. The settlement of the settled debt is made by phased payment in accordance with the conditions and procedure approved by the Government of the Russian Federation, or by an agreement or decision. Figure 6 shows the dynamics of various types of debt according to the above classification criteria.

In Russia, the indicator is the ratio of the tax debt to the volume of taxes, fees, insurance contributions to the budget system of the Russian Federation. This indicator characterizes the efficiency of the tax authorities in the settlement of tax arrears. Picture 5 shows the dynamics of this indicator over 13 years. 


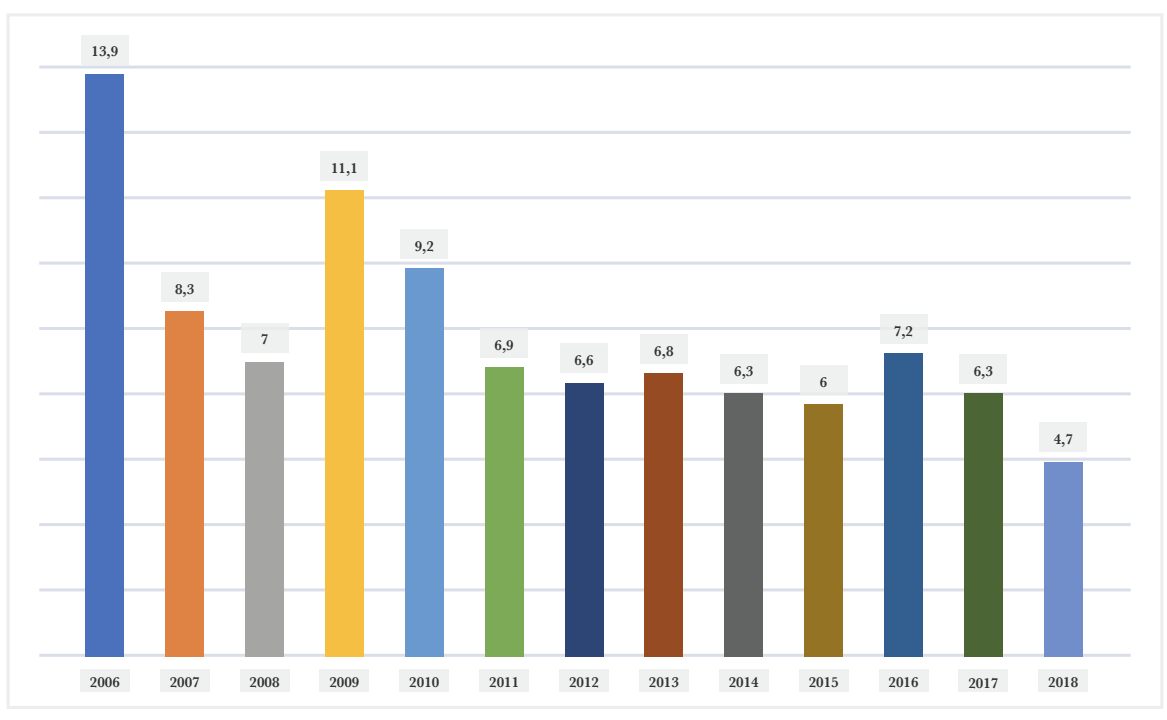

Picture 5. The ratio of the tax debt to the amount of taxes, fees, insurance premiums in the budget system of the Russian Federation, in \%.

In the Russian Federation, there is a tendency to a decrease in the ratio of the tax debt to the volume of taxes, fees, insurance contributions to the budget system of the Russian Federation. So, in 2018 compared with 2006, this ratio decreased by more than 2 times. Also in Figure 2 one can observe a noticeable increase in the ratio of debt to revenues in 2009 compared with 2008 by $2.1 \%$, and in 2016 compared with 2015 by $1.2 \%$. These phenomena are associated with global financial crises. However, it should be noted that the decrease in this indicator in subsequent years is due to a significant increase in taxes, fees, insurance contributions to the budget system of the Russian Federation. Therefore, further development of measures to reduce tax arrears is necessary.

It should be noted that in Russia as a whole, the tax debt of both individuals and legal entities increases annually, although as of January 1, 2018 compared with January 1, 2017, this indicator for legal entities decreased by $1.87 \%$ (Picture 6). 


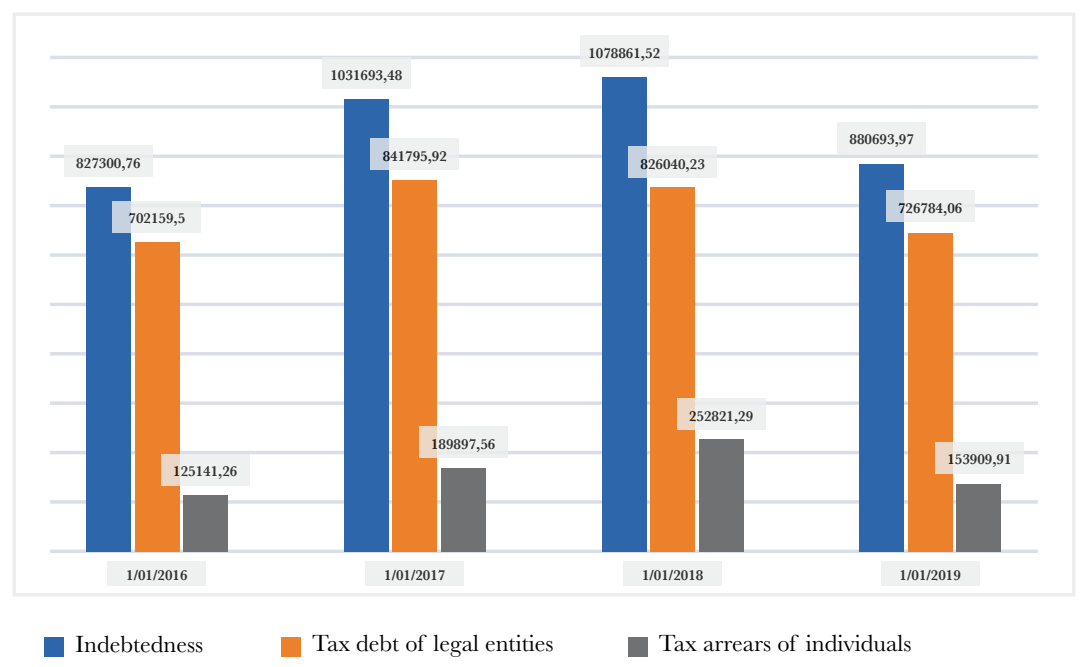

Picture 6. Dynamics of total tax debt in the whole of the Russian Federation.

The total tax debt in Russia increased by 30\% in 2017 compared to 2015. The main reason for the growth of aggregate tax debt is the additional charges on control work and crisis phenomena in the economy. The largest share in total tax debt is tax debt of legal entities - more than $75 \%$.

It should be noted that tax audits are not the cause of arrears, but only record the facts of violation of legislation on taxes and fees, as a result of which tax arrears of both legal entities and individuals arise. Conducting control measures in relation to taxpayers by the tax authorities does not always lead to the state budget receiving the full amount of taxes and fees, as reflected in the decision to prosecute tax violations. Such a result is possible if the organization does not have at the time of the control measures and after they have completed the property and current assets for repayment of the sums generated as a result of the audit.

To assess the effectiveness of the tax authorities, including tax control over the debt, the tax audit performance indicators and the amount of additionally accrued payments based on the results of tax audits (Table 1) (Orlova \& Kashapova, 2018) are used. 
Table 1. Dynamics of data on the results of tax audits in Russia.

\begin{tabular}{|c|c|c|c|c|}
\hline Indications & 2015 & 2016 & 2017 & 2018 \\
\hline \multicolumn{5}{|c|}{ Cameral tax audit } \\
\hline $\begin{array}{l}\text { The number of cameral } \\
\text { tax audits, in units }\end{array}$ & 31932225 & 39978278 & 55859670 & 67889196 \\
\hline $\begin{array}{l}\text { The number of cameral } \\
\text { tax audits that revealed } \\
\text { violations in units }\end{array}$ & 1948540 & 2254497 & 3014277 & 3531037 \\
\hline $\begin{array}{l}\text { The effectiveness of } \\
\text { cameral tax audits, in } \%\end{array}$ & 6,1 & 5,6 & 5,4 & 5,2 \\
\hline $\begin{array}{l}\text { Additionally accrued } \\
\text { payments, in thousand } \\
\text { rubles, of which: }\end{array}$ & 74233338 & 98491131 & 61559605 & 55659611 \\
\hline - Taxes & 60003911 & 73020626 & 41812328 & 36678972 \\
\hline \multicolumn{5}{|c|}{ Field Tax audit } \\
\hline $\begin{array}{l}\text { Number of field tax } \\
\text { audits, in units }\end{array}$ & 29393 & 24879 & 19391 & 13738 \\
\hline $\begin{array}{l}\text { The number of field tax } \\
\text { audits that revealed } \\
\text { violations in units. }\end{array}$ & 29118 & 24670 & 19134 & 13444 \\
\hline $\begin{array}{l}\text { The effectiveness of field } \\
\text { tax audits, in } \%\end{array}$ & 99,1 & 99,2 & 98,7 & 97,9 \\
\hline $\begin{array}{l}\text { Additionally accrued } \\
\text { payments, in thousand } \\
\text { rubles, of which: }\end{array}$ & 265239993 & 348632418 & 309863053 & 306199093 \\
\hline - Taxes & 195988031 & 251919710 & 221485332 & 2170984117 \\
\hline
\end{tabular}

The number of off-site tax audits significantly exceeds the number of on-site tax audits, respectively, the indicators of additionally accrued payments identified as a result of on-site tax audits are significantly higher than during the desk tax audits. This is due to the fact that the on-site tax audit allows tax authorities to verify various areas and aspects of taxpayers' activities. It is necessary to recognize that when conducting a field audit, the tax authorities have much more powers than the office audit. Upon completion of both the cameral tax audit and the on-site tax audit, the tax authorities are tasked with collecting the arrears, penalties and fines for them. But in practice, tax debt collection is not so easy.

\section{SUMMARY}

Having summarized the opinions of various economists, and, having analyzed the dynamics and structure of tax debts, we consider it possible to clarify the definition of tax debts from the point of view of its economic essence. Tax arrears 
can be defined as a set of unfulfilled obligations to pay the statutory taxes and fees, accrued penalties for late payment of taxes and fees, and awarded penalties for violating tax laws expressed in monetary form.

From the point of view of tax administration, it is necessary to clarify the definition of settled and unregulated tax arrears. Regulated tax debt is a debt with which the tax authority may conduct administrative measures (settlement methods), incl. change in the deadlines for the payment of taxes and other obligations (deferment, installment plan, investment tax credit), procedures of indisputable and compulsory collection, up to and including the initiation of a bankruptcy procedure and write-off. Unresolved tax arrears are arrears in respect of which indisputable penalties have not yet been applied, as well as uncollectible tax arrears, i.e. one that cannot be recovered due to certain circumstances and arrears. The proposed definitions of "settled, unresolved" debt should be consolidated legislatively, it will help to increase the tax discipline of tax payers.

Within the framework of the specifics of settled debt, it would be possible to suggest one more group of tax debts: tax debts, for which reconciliation of calculations was carried out and tax debts for which this reconciliation was not performed. In this regard, it is advisable to recommend adjusting the reconciliation of calculations with the budget at the level of the Tax Code of the Russian Federation, and not by-laws.

In conclusion, you can reflect the general model of tax debt for its various types (Picture 7). 


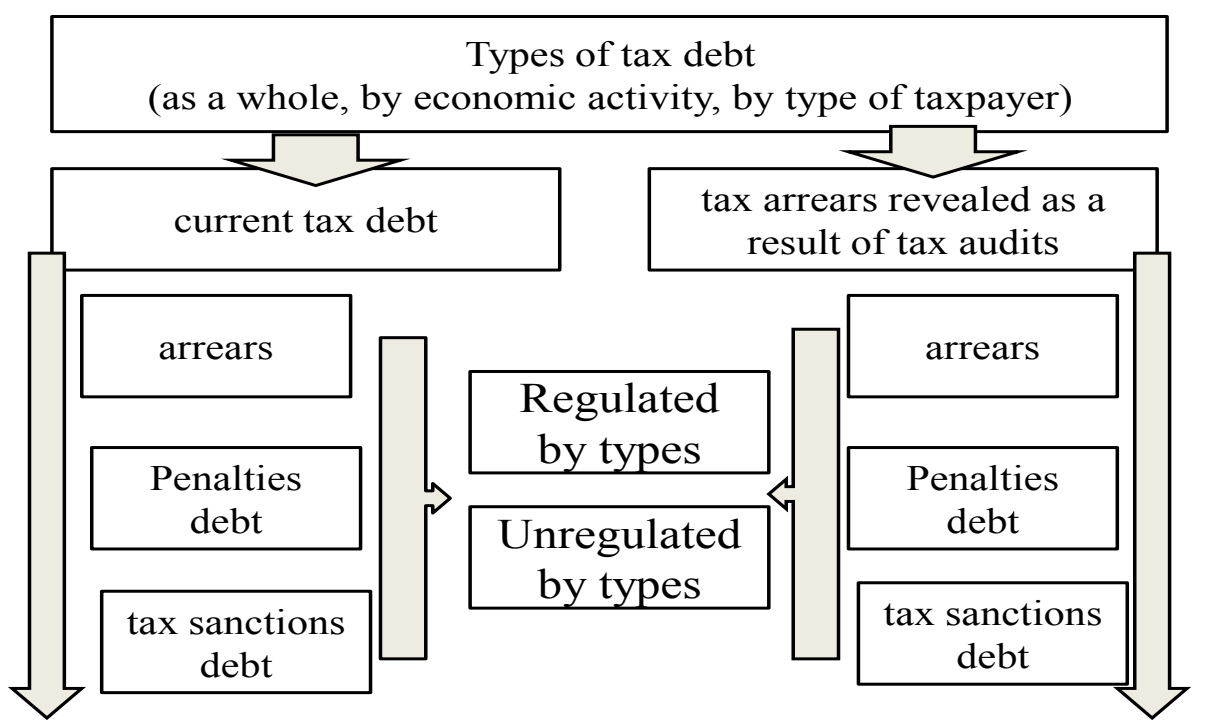

Picture 7. Classification of tax debt for tax administration purposes.

Interesting for tax administration purposes would be to use the tax debt classification by type of organizations-debtors, including by type of economic activity. This will improve the performance of the tax authorities to collect tax debts. It seems appropriate to develop a program of actions for administering different types of taxpayers and collecting tax arrears, and in the future, it is possible to prevent the occurrence of tax arrears.

\section{CONCLUSIONS}

In order to improve tax legislation and reduce tax debt, contributing to the development of tax control over debt, you can offer:

- To carry out bankruptcy prevention through the organization of financial monitoring of the state of affairs, both in each organization and the industry as a whole, developing a mechanism for crisis management, closing down unprofitable production and forecasting bankruptcies of insolvent and unprofitable organizations; 
- Tax authorities should be allowed to request documents from both taxpayers and counterparties outside tax audits in order to monitor the financial situation. Diagnosis of bankruptcy and crisis management will prevent the growing number of bankruptcies, will avoid the liquidation of many enterprises, which has a great influence on the level of tax debt in the Russian Federation as a whole;

- It is necessary to reduce the period of enforcement proceedings by bailiffs to 3 months, in order to improve the organization of interaction between tax authorities and the bailiff service and full control over the course of enforcement proceedings by tax authorities. Improving cooperation with the bailiff service will reduce the time needed to collect debts in the framework of enforcement proceedings and pay off taxpayers with debt from liquid assets in the course of enforcement proceedings.

Thus, the improvement of the mechanisms of tax authorities aimed at identifying tax debts becomes a very urgent task of tax legislation due to shortcomings that contribute to the growth of tax debts of both legal entities and individuals.

\section{ACKNOWLEDGEMENT}

The work is performed according to the Russian Government Program of Competitive Growth of Kazan Federal University.

\section{REFERENCES}

Aushev, T. A. (2004). Organizational and Economic Preconditions of Tax Debt and Ways to Reduce It.

Bondar, O. A. (2011). Cumulative tax liability: prerequisites and problems of its reduction. Power and Administration in the East of Russia, 1, 55-62.

Isaev, K. K. (2000). Reduction of Tax Payments of Enterprises in the Regional Economy. 
Lebedev, K. N. (1998). The concept, composition and legal regime of accounts payable. Economic Law, 11.

Official site of the Federal Tax Service of Russia. (2019). Statistics and analytics. Retrieved from http://nalog.ru

Orlova, M. E., \& Kashapova, R. R. (2018). Tax debt and its current status in Russia. Monthly International Scientific Fournal European Multi Science Fournal, 17, $39-46$.

Ozhegov, S. I. (1986). Dictionary of Ozhegov. Russian.

Pronin, S. B. (2016). Recovery of tax arrears from organizations. Accountant's Hotline, 9.

Raizberg, B. A., Lozovsky, L. Sh., \& Starodubtseva, Ye. B. (1999). Modern Economic Dictionary. INFRA-M.

Ushakov, D. N. (1935). Tolkovy Dictionary Ushakov. 